\title{
MULTIPLE-SET SPLIT FEASIBILITY PROBLEMS FOR A FINITE FAMILY OF DEMICONTRACTIVE MAPPINGS IN HILBERT SPACES
}

\author{
LI-JUAN QIN AND GANG WANG
}

Abstract. In this paper, we introduce an iterative algorithm for solving the multiple-set split feasibility problems for a finite family demicontractive mappings in Hilbert spaces. The results presented in this paper improve and extend some recent corresponding results in [4], [7], [9], [10], [13], [14].

Mathematics subject classification (2010): 47H09, 47J25.

Keywords and phrases: Multiple-set split feasibility problem, demicontractive mapping, demi-closed, fixed point.

\section{REFERENCES}

[1] Y. Censor, T. Elfving, A multiprojection algorithm using Bregman projection in a product splace, Numer. Algorithms, 8 (1994), 221-239.

[2] C. B Y RNE, Iterative oblique projection onto convex subsets and the split feasibility problems, Inverse Problem, 18 (2002), 441-453.

[3] Y. Censor, T. BortFeld, B. Martin, T. TRofimov, A unified approach for inversion problem in intensity-modolated radiation therapy, Phys. Med. Biol., 51 (2006), 2353-2365.

[4] Y. CENSOR, T. ElFVING, N. KOPF, T. BORTFELD, The multiple-sets split feasibility problem and its applications, Inverse Problem, 21 (2005), 2071-2084.

[5] Y. Censor, A. Motova, A. Segal, Pertured projections and subgradient projections for the multiple-sets split feasibility problems, J. Math. Anal. Appl., 327 (2007), 1244-1256.

[6] H. K. XU, A variable Krasnosel'skii-Mann algorithm and the multiple-set split feasibility problem, Inverse Problem, 22 (2006), 2021-2034.

[7] F. WANG, H. K. XU, Approximation curve and strong convergence of the CQ algorithm for the split feasibility problem, J. Inequalities Appl., (2010), doi:10.1155/2010/102085.

[8] G. LOPEZ, V. MARTIN, H. K. XU, Iterative algorithms for the muitiple-sets split feasibility problem, In: Y. Censor, M. Jiang, G. Wang (eds) Biomedical Mathematics: Promising Directions in Imaging, Therapy Planning and inverse Problems, pp. 243-279, Medical Physics Publishing, Madison (2009).

[9] H. K. XU, Iterative methods for split feasibility problem in infinite-dimensional Hilbert spaces, Inverse Problem, 26, (2010), 105018 (17 pp).

[10] Q. YANG, The relaxed CQ algorithm for solving the split feasibility problem, Inverse Problem, 20, (2004), 1261-1266.

[11] J. ZHANG, Q. YANG, Several solution methods for the split feasibility problem, Inverse Problem, 21, (2005), 1791-1799.

[12] S. Maruster, C. Popirlan, On the Mann-type iteration and convex feasibility problem, J. Comput. Appl. Math., 212, (2008), 390-396.

[13] A. MoudAFI, A note on the split common fixed point problem for quasi-nonexpansive operators, Nonlinear Anal., 74, (2011), 4083-4087.

[14] A. MOUDAFI, The split common fixed point problem for demi-contractive mappings, Inverse problem, 26, (2010), 055007 (6 pp). 